(C) Воронцова А.С., Артюхов А.С., Барвінок В.Ю., 2021

a.vorontsova@uabs.sumdu.edu.ua, a.artyukhov@pohnp.sumdu.edu.ua, veronika.barvinok@gmail.com

Сумський державний університет, Суми

\title{
ІДЕНТИФІКАЦЯ ОСНОВНИХ СТЕЙКХОЛДЕРІВ У СИСТЕМІ ОСВІТИ ВПРОДОВЖ ЖИТТЯ ДЛЯ ЗАПОБІГАННЯ ТРУДОВІЙ ЕМІГРАЦІї
}

\begin{abstract}
Досліджено теоретичну суть поняття «стейкхолдер» як основну категорію теорії зацікавлених сторін, розглянено основні класифікаційні ознаки, за якими можна виділити стейкхолдерів, відповідно до різних наукових підходів. На основі иьього проаналізовано основних стейкхолдерів системи освіти впродовж життя та ринку праці як місия трудової міграції, запропоновано їх ранжування за рівнем $і$ ступенем впливу, належністю до держави та якісними характеристиками.
\end{abstract}

Ключові слова: стейкхолдер, теорія зацікавлених сторін, класифікація, система освіти.

Постановка проблеми. Забезпечення якісної системи освіти - одне із пріоритетних завдань уряду будь-якої країни, адже вона зумовлює формування кваліфікованої робочої сили, без якої неможлива діяльність будь-якої сфери економіки, та сприяє соціальному благополуччю населення. Вдала організована освітня система, що взаємодіє з ринком праці та готує тих спеціалістів, у яких у нагальному часі $\epsilon$ потреба, $\epsilon$ запорукою запобігання трудової еміграції. У такому контексті, особливої актуальності набуває питання ідентифікації основних зацікавлених осіб, або стейкхолдерів, які існують у системі освіти впродовж життя для запобігання трудовій міграції.

Сама по собі система освіти впродовж життя $\epsilon$ складною структурою, яка охоплює багато взаємопов 'язаних суб'єктів у змінному зовнішньому та внутрішньому середовищі. Це зумовлює необхідність їх класифікації та групування для можливого виявлення в подальшому їх ключових інтересів i сфер впливу, можливих напрямів взаємодії з ними та полегшення реалізації конкретних стратегічних і тактичних рішень чи організаційних цілей.

Аналіз останніх досліджень і публікацій. Дослідження теорії зацікавлених осіб займає особливе місце в науковій літературі, що бере свій початок з розвитку основ менеджменту (Е. Фрімен [2], Р. Мітчелл, Б. Егл, Д. Вуд [4] тощо). Серед вітчизняних науковців дане питання досліджувалося у працях Аммарі А.О. [5], Нохріної Л.А. [9], Тимошенкова І.В. та Нащекіної О.М. [13], Мирошниченко Ю.О., Бондар А.В. [8] тощо. В окремих працях відбулася адаптація основ теорії стейкхолдерів до галузі освіти, зокрема: Піскурська Г. В. [11], Жегус О. В. [7] тощо.
Виділення не розв'язаних раніше частин загальної проблеми. Незважаючи на численні дослідження в даній сфері, питання адаптації стейкхолдерського підходу до системи освіти впродовж життя 3 метою запобігання трудовій еміграції населення, що дозволить класифікувати ключових стейкхолдерів і визначити їх рівень впливу, залишається, на нашу думку, недостатньо дослідженим і потребує подальшого розвитку.

Формулювання цілей статті. Метою статті $€$ проведення теоретичної ідентифікації та класифікації ключових стейкхолдерів у системі освіти впродовж життя для запобігання трудовій міграції.

Виклад основного матеріалу дослідження. Поняття «стейкхолдер» (з англ. - «stakeholder») виникло в контексті розвитку інституціонального напрямку теорії підприємства (фірми) та згодом сформувалося в окрему теорію стейкхолдерів (або зацікавлених сторін, що буде вживатися нами як синонім). Сам термін почав використовуватися у 60-х $-80-\mathrm{x}$ роках $\mathrm{XX}$ століття в менеджменті, найчастіше його приписують Р. Фрімену (R. E. Freeman). За його на сьогодні вже класичним визначенням, до стейкхолдерів відносяться «всі ті індивідууми та ї групи, які або самі впливають на організацію, або відчувають на собі іiі вплив» [2]. У сучасних умовах теорію стейкхолдерів прийнято застосовувати не лише відносно підприємств та організацій (приватних суб'єктів), а й щодо інших сфер діяльності. Саме тому в подальшому будемо використовувати більш загальний термін суб'єкт господарювання замість фірми, що можна застосувати і в освітній галузі.

У загальному вигляді теорія зацікавлених сторін (стейкхолдерів) базується на трьох основних моментах: 
1. Економічна діяльність характеризується наявністю специфічних відносин між суб'єктами господарювання та їх зацікавленими сторонами. Водночас існує взаємозв'язок між діяльністю зацікавлених сторін.

2. Узаємозв'язок і взаємозалежність можуть принести потенційну користь для всіх сторін.

3. Кожна зацікавлена сторона має свої конкретні очікування щодо різних аспектів функціонування суб'єкта господарювання: організаційних, економічних, соціальних, екологічних тощо [2].

Відповідно до теоретичних основ галузі менеджменту, стейкхолдер - це «суб'єкт, який володіє репутацією, владою або іншими ресурсами, інвестованим у проєкт, та до певної міри бере на себе будь-які ризики цього проєкту» [5]. Додатково визначають, що стейкхолдерами $\epsilon$ «всі особи або групи осіб, які є об'єктами або суб'єктами діяльності та політики компанії як на місцевому, так і глобальному рівнях» [5].

Тісно із теорією зацікавлених сторін пов'язаний стандарт менеджменту ISO 26000:2010 «Настанова по соціальній відповідальності», який призначений для надання організаціям вказівок щодо соціальної відповідальності і може бути використаний як частина діяльності державної політики. У стандарті визначені два основні аспекти соціальної відповідальності: 1) організація розуміє, як іiі діяльність впливає на інших і на довкілля; 2) організація розуміє суспільні очікування своєї соціально відповідальної поведінки [3]. Це показує важливість урахування інтересів широкого кола зацікавлених сторін при проведенні політики соціальної відповідальності.

Плюаралізм підходів до визначення суті стейкхолдерів зумовлений їх достатньо великим колом поширення, спрямуванням діяльності на досягнення різних інтересів тощо. У цьому контексті доцільно розглянути основні їх класифікаційні ознаки, які виділяються науковцями.

За належністю до суб'єкта господарювання стейкхолдерів прийнято класифікувати на внутрішніх (наприклад, персонал, акціонери тощо) i зовнішніх (клієнти, постачальники, суспільство тощо). Більш того, зацікавлених осіб можна умовно розділити за рівнем впливу на прямих i непрямих (опосередкованих). До основних належать «власники, персонал, місцеві громади, клієнти, постачальники та бізнеспартнери. До непрямих - 3MI, професійні об'єднання, активісти, конкуренти, органи державного управління, некомерційні та суспільні організації» [5].
А. Амарі [5] пропонує класифікувати стейкхолдерів за належністю до певної сфери впливу: соціальної (наприклад, населення, персонал, клієнти, конкуренти); громадської (державні та громадські організації, територіальні громади, засоби масової інформації); економічної (бізнес-середовище, фінансові організації, інвестори тощо); наукової тощо.

Заслуговує на увагу і підхід групи авторів, які пропонують виділяти стейкхолдерів на основі таких принципів: суб'єкти, які мають інтерес до рішень та/або їх наслідків (або перед якими маються певні зобов'язання); суб'єкти, які будуть впливати на рішення; суб'єкти, на які можливо або точно буде здійснено вплив $[8,14]$. При цьому такий вплив може носити як позитивний, так і негативний характер.

Відповідно до Стандарту взаємодії зі стейкхолдерами (AA1000SES), розробленого організацією «AccountAbility», основні критерії для ідентифікації стейкхолдерів такі:

- відповідальність, тобто перед зацікавленими особами $\epsilon$ ряд зобов'язань (юридичні, фінансові, виробничі, етичні), які юридично чи організаційно-методично закріплені;

- вплив - зацікавлені особи мають влив на організацію чи уповноважені приймати рішення, що стосуються суб' єктів господарювання;

- близькість, тобто з такими стейкхолдерами існують тісні та тривалі взаємовідносини;

- залежність - зацікавлені сторони залежать від суб'єкта господарювання прямо чи опосередковано, в економічному плані чи належності до спільної інфраструктури тощо;

- представництво та політичні/стратегічні наміри [1].

У наукових колах окремі науковці виділяють стейкхолдерів на основі співвідношення влади та інтересів. Група авторів на чолі iз Р. Мітчеллом пропонують класифікацію стейкхолдерів на основі наявності в них таких атрибутів: влади, легітимності (законності) і терміновості вимог. Залежно від їх співвідношення прийнято виділяти класи стейкхолдерів: латентні (1/3 атрибутів); клас очікування (2/3 атрибутів); категоричні (3/3 атрибутів). Кожен з яких, залежно від комбінації атрибутів, має свої групи (наприклад, до класу очікування належать: група домінування (влади + легітимність); залежна група (легітимність + терміновість); небезпечна група (влада + терміновість)).[13].

Проведений теоретичний аналіз понятійного апарату й основних класифікаційних ознак у 
теорії стейкхолдерів дозволяє спроєктувати ii положення на сферу освіти впродовж життя та ринок праці, на якому відбувається в подальшому трудова міграція населення.

У законодавстві України про освіту поки що не визначено поняття «стейкхолдер», але зазначені суб'єкти, що прямо або опосередковано причетні до освітньої діяльності та які здійснюють на неї вплив. Відповідно до Закону України «Про вищу освіту», основними суб'єктами системи освіти є: держава, яка представлена Верховною Радою України, Кабінетом Міністрів України, Міністерством освіти та науки, а також Національне агентство із забезпечення якості вищої освіти, Національна академія наук України, керівництво закладів освіти, адміністрація закладів вищої освіти (далі - 3ВО), наукові установи, педагогічні, науковопедагогічні та наукові працівниками 3ВО, наглядова (піклувальна) рада закладу освіти, здобувачі освіти (студенти), батьки здобувачів освіти та інші суб'єкти освітньої діяльності [10, $12,6,13]$.

Отже, визначальними стейкхолдерами в українській системі освіти $є$ саме державноінституційні суб'єкти. Так, Верховна Рада - це вищий законодавчий орган, а Кабінет Міністрів, Міністерство освіти i науки України та Національне агентство із забезпечення якості вищої освіти - органи виконавчої влади. Разом вони формують соціальний курс розвитку держави у сфері освіти 3 відповідними наслідками для ринку робочої сили. Профільне міністерство узгоджує дії усіх учасників освітнього процесу, ухвалює, контролює дотримання правил $\mathrm{i}$ вимог до професійної підготовки. На інституціональному рівні держава має можливість заохотити заклади вищої освіти та підприємства до щільних взаємин, залучати бізнес до освітнього процесу тощо [12].

Зазначимо, що здобувачі освіти є не менш важливими учасниками системи освіти та в подальшому ринку праці. Згідно 3 освітнім законодавством, до здобувачів відносять: «вихованців, учнів, студентів, курсантів, слухачів, стажистистів, аспірантів (ад'юнктів), докторантів та інших осіб, які здобувають освіту за будь-яким видом і формою здобуття освіти» [12]. Батьки здобувачів також займають не останню роль в освіті, саме вони сприяють виконанню дитиною освітньої програми та впливають на досягнення передбачених нею результатів навчання. Разом здобувачі та їх батьки утворюють окрему групу стейкхолдерів. Влада цієї групи визначається залежністю від неї навчальних закладів. Попри все, ця залежність постійно підсилюється через негативні демографічні тенденції, зростання конкуренції на ринку освітніх послуг i недостатнє бюджетне фінансування освіти. Якщо ця група не висуває реального попиту на високоякісну освітню підготовку, то навчальні заклади змушені адаптувати свою діяльність відповідно до їхніх інтересів - тобто послаблювати вимоги до студентів і знижувати критерії якості навчання. А спадання попиту з боку цих стейкхолдерів на якісну освіту є віддзеркаленням загального стану економіки й відсутності в суспільстві дієвих стимулів для розвитку продуктивної, а не перерозподільної діяльності [12].

Ключовими стейкхолдерами ринку праці в контексті питання гальмування трудової міграції, які визначені законодавством України, є: Міжнародна організація 3 міграції, Державна міграційна служба України, Державна служба зайнятості, професійні асоціації та об'єднання роботодавців, профспілки, роботодавці, їх об'єднання та професійні асоціації та інші.

Державна міграційна служба України $є$ зацікавленою стороною, що бере участь у вирішенні питань трудової міграції та питань, пов'язаних із навчанням в Україні іноземців та осіб без громадянства, формує державне замовлення на підготовку фахівців у відповідній сфері, здійснює міжнародне співробітництво, бере участь у розробленні проектів та укладенні міжнародних договорів України 3 питань громадянства, міграції, біженців, осіб, які потребують інших форм захисту, реєстрації фізичних осіб і реадмісії, забезпечує в межах своїх повноважень виконання укладених міжнародних договорів України [10].

Найбільший вплив на працевлаштування населення має саме Державна служба зайнятості, оскільки саме цей орган здійснює реалізацію державної політики у сфері зайнятості населення та трудової міграції, соціального захисту від безробіття й аналізує стану ринку праці 3 подальшим прогнозом попит i пропозицію на робочу силу [15]. Разом 3 тим, дана служба створює умови для формальної, неформальної та інформальної освіти дорослих.

Об'єднуючою групою стейкхолдерів між системою освіти та ринком праці є керівництво закладів вищої освіти, яке створює і утримує мережу закладів освіти та їхніх філій. У сфері освіти вони забезпечують органічне поєднання у освітньої, наукової та інноваційної діяльності, створення необхідних умов для реалізації учасниками освітнього процесу їхніх здібностей і талантів, а у сфері працевлаштування - у забезпеченні суспільного та економічного 


\section{ІДЕНТИФІКАЦІЯ ОСНОВНИХ СТЕЙКХОЛДЕРІВ У СИСТЕМІ ОСВІТИ ВПРОДОВЖ ЖИТТЯ ДЛЯ ЗАПОБІГАННЯ ТРУДОВІЙ ЕМІГРАЦЇ̈}

розвитку держави через формування людського капіталу, вивчення попиту на окремі спеціальності на ринку праці та сприяння працевлаштуванню випускників і провадження на високому рівні освітньої діяльності, яка забезпечує здобуття особами вищої освіти відповідного ступеня за обраними ними спеціальностями $[12,13]$.

На основі проведеного дослідження узагальнимо інформацію щодо ключових стейкхолдерів у системі освіти впродовж життя для запобігання трудовій еміграції у таблиці 1.

\section{Класифікація основних стейкхолдерів у системі освіти впродовж життя для запобігання трудовій еміграції}

\begin{tabular}{|c|c|c|c|}
\hline Стейкхолдери & $\begin{array}{c}\text { За ступенем } \\
\text { впливу }\end{array}$ & $\begin{array}{c}\text { За приналежністю } \\
\text { до держави }\end{array}$ & $\begin{array}{c}\text { За якісними } \\
\text { характеристиками } \\
\end{array}$ \\
\hline \multicolumn{4}{|c|}{ За рівнем впливу - макрорівень } \\
\hline $\begin{array}{l}\text { 1. Міжнародні організації (міжнародна } \\
\text { організація } 3 \text { міграції, ЮНЕСКО тощо) }\end{array}$ & Середній & Зовнішні & Домінуючі \\
\hline 2. Верховна Рада України & Високий & Внутрішні & Домінуючо-дефінітивні \\
\hline 3. Кабінет Міністрів України & Високий & Внутрішні & Домінуючо-дефінітивні \\
\hline 4. Міністерство освіти та науки України & Високий & Внутрішні & Домінуючо-дефінітивні \\
\hline 5. Державна міграційна служба України & Високий & Внутрішні & Домінуючо-дефінітивні \\
\hline 6. Державна служба зайнятості & Високий & Внутрішні & Домінуючо-дефінітивні \\
\hline $\begin{array}{l}\text { 7. Національне агентство із забезпечення } \\
\text { якості вищої освіти }\end{array}$ & Високий & Внутрішні & Домінуючий \\
\hline 8. Органи місцевого самоврядування & Високий & Внутрішні & Домінуючо-дефінітивні \\
\hline \multicolumn{4}{|c|}{ За рівнем впливу - мезорівень } \\
\hline $\begin{array}{l}\text { 9. Професійні асоціації та об’єднання } \\
\text { роботодавців }\end{array}$ & Низький & Внутрішні & Залежні \\
\hline 10. Торгово-промислові палати & Середній & Внутрішні & Залежні \\
\hline 11. Профспілки & Низький & Внутрішні & Залежні \\
\hline 12. Неурядові організації & Низький & Внутрішні & Бездіяльні \\
\hline 13. Засоби масової інформації & Низький & Внутрішні & Небезпечні \\
\hline \multicolumn{4}{|c|}{ За рівнем впливу - мікрорівень } \\
\hline 14. Керівництво ЗВО & Високий & Внутрішні & Домінуючо-дефінітивні \\
\hline $\begin{array}{l}\text { 15. Педагогічні, науково-педагогічні та } \\
\text { наукові працівниками ЗВО }\end{array}$ & Низький & Внутрішні & Бездіяльні \\
\hline 16. Здобувачі освіти (студенти) & Високий & Внутрішні & Дискреційні \\
\hline 17. Батьки здобувачів освіти & Високий & Внутрішні & Дискреційні \\
\hline $\begin{array}{l}\text { 18. Наглядова (піклувальна) рада закладу } \\
\text { освіти }\end{array}$ & Середній & Внутрішні & Бездіяльні \\
\hline
\end{tabular}

*Джерело: згруповано авторами на основі [5, 9, 15 тощчо].

Висновки 3 даного дослідження та перспективи подальших розвідок у даному напрямку. На сьогодні стейкхолдерський підхід став достатньо популярним і використовується в різних сферах діяльності, у тому числі в освіті. Це дозволяє ідентифікувати найбільш впливові зацікавлені сторони, що дає змогу врахувати їх інтереси. На основі досліджених наукових розробок визначено суть i основні характеристики стейкхолдерів, виділено основні ïх класифікаційні ознаки. У роботі обрано такі ознаки, за якими були згруповані стейкхолдери: за рівнем (мікро-, мезо- та макро-) та ступенем впливу (важливий, середній, низький), за належністю до держави (внутрішні та зовнішні) та якісними характеристиками (бездіяльні, дискреційні, вимогливі, домінуючі, небезпечні, залежні, дефінітивні). На основі цього визначені ключові стейкхолдери в системі освіти впродовж життя для запобігання трудовій міграції.

Робота виконана у рамках держбюджетної науково-дослідної розробки «Реформування системи освіти впродовж життя в Украйні для запобігання трудовій еміграиії: компетиційна модель інституиійного партнерства» (номер державної реєстрачіï: 0120U102001), «Конвергенція економічних та освітніх трансформацій в ичирровому суспільстві: моделювання виливу на регіональну та начіональну безпеку» (номер державної реєстраиiї: 0121U109553). 


\section{Список літератури}

1. AA1000 Stakeholder Engagement Standard. 2015. 40 p. URL: https://www.accountability. org/wpcontent/uploads/2016/10/AA1000SES_2015.pdf. (дата звернення: 30.05.2020).

2. Freeman R. E. The Stakeholder Approach Revisited. Zeitschrift für Wirtschafts- und Unternehmensethik. 2004. №5. URL: https://www.researchgate.net/publication/228946075_

The_Stakeholder_Approach_Revisited. (дата звернення: 30.05.2020).

3. ISO 26000:2010. Guidance on social responsibility. URL: https://www.iso.org/standard/42546.html. (дата звернення: 30.05.2020).

4. Mitchell R., Agle B., Wood D. Toward a Theory of Stakeholder Identification and Salience: Defining the Principle of Who and What Really Counts. The Academy of Management Review. 1997. №22. p. 853-886.

5. Аммарі А.О. Класифікація стейкхолдерів на основі взаємних очікувань. Актуальні проблеми економіки. 2012. № 8. С. 150-155.

6. Вербицька С. В.. Міжнародна студентська академічна мобільність: етапи розвитку та суб'єкти організації. Вісник Житомирського державного університету. 2009. Вип. 45. С. 20-26. URL:http://eprints.zu.edu.ua/3047/1/4_45.pdf. (дата звернення: 30.05.2020).

7. Жегус О. В. Ключові стейкхолдери закладу вищої освіти на галузевому ринку. Східна Європа: економіка, бізнес та управління. 2018. № 15. С. 170178.

8. Мирошниченко Ю.О., Бондар А.В. Модель взаємодії стейкхолдерів у реальному секторі економіки України в контексті КСВ. Східна Свропа: Економіка, бізнес та управління. 2018. Вип. 5. С. 71 74.

9. Нохріна Л. А. Алгоритм ідентифікації груп стейкхолдерів. Місто. Культура. Цивілізація : матеріали V міжнар. наук.-теор. інтернет-конф. Харків : ХНУМГ ім. О. М. Бекетова, 2015. С. 168-175. C. 168-175. URL: http://eprints.kname.edu.ua/40107/1/168-175.pdf. (дата звернення: 30.05.2020).

10. Офіційний сайт Державної міграційної служби України. URL: https://dmsu.gov.ua/pro-dms/zagalnainformacziya.html. (дата звернення: 30.05.2020).

11. Піскурська Г. В. Стейкхолдерський підхід у забезпеченні якості вищої освіти. Педагогіка, психологія і соиіологія. 2019. № 1 (24). С. 69-77.

12. Про вищу освіту : закон України. Закон України від 01.07.2014 № 1556-VII. URL: http://zakon.rada.gov.ua/laws/show/1556-18. (дата звернення: 30.05 .2020$)$.

13. Тимошенков I. В., Нащекіна О. М. Суб'єкти, агенти, актори i стейкхолдери в економічних дослідженнях освіти. Вчені записки ХГУ «НУА». 2012. Т. 18, кн. 1 :Освіта: традиції та інновації в умовах соціальних змін. С. 167-176.

14. Участие заинтересованных сторон в принятии решений: теория и практика взаимодействия/ К. И. Степаненко, Е. В. Перфильева, под ред. Е. В. Перфильевой. Новокузнецк: ИнЭкА, 2018.120 с.

15. Фоменко К. М. Роль державної служби зайнятості в професійній орієнтації учнівської молоді. Науковий пошук молодих дослідників : збірник наукових прачь студентів. 2012. №8. С. 5-13.

\section{References}

1. AA1000 Stakeholder Engagement Standard (2015). URL: https://www.accountability. org/wpcontent/uploads/2016/10/AA1000SES_2015.pdf.

(Accessed 30.05.2020).

2. Freeman, R. E. (2004), "The Stakeholder Approach Revisited", Zeitschrift für Wirtschafts- und Unternehmensethik, $5 . \quad$ URL: https://www.researchgate.net/publication/228946075

The_Stakeholder_Approach_Revisited. (Accessed 30.05.2020).

3. ISO 26000:2010. Guidance on social responsibility. https://www.iso.org/standard/42546.html. (Accessed 30.05.2020).

4. Mitchell, R., Agle, B., Wood, D. (1997), “Toward a Theory of Stakeholder Identification and Salience: Defining the Principle of Who and What Really Counts", The Academy of Management Review, 22, pp. 853-886.

5. Ammari, A.O. (2012), "Classification of stakeholders based on mutual expectations", Aktualni problemy ekonomiky, 8, pp. 150-155.
6. Verbyt'ka, S. V. (2009), "International student academic mobility: stages of development and subjects of organization", Visnyk Zhytomyrs'koho derzhavnoho universytetu, 45, pp. 20-26. URL:http://eprints.zu.edu.ua/3047/1/4_45.pdf. (Accessed 30.05.2020).

7. Zhehus, O. V. (2018), "Key stakeholders of higher education institutions in the industry market", Eastern Europe: Economy, Business and Management, 15, pp. 170-178.

8. Myroshnychenko, YU.O., Bondar, A.V. (2018), “ Model of stakeholder interaction in the real sector of the Ukrainian economy in the context of CSR", Eastern Europe: Economy, Business and Management, 5, pp. 7174.

9. Nokhrina, L. A. (2015), “Algorithm for identifying groups of stakeholders", materials of the V International. scientific-theoretical internet conference, Misto. Kul'tura. Tsyvilizatsiya [City. Culture. Civilization], Kharkiv, pp. 168-175. URL: http://eprints.kname.edu.ua/40107/1/168175.pdf. (Accessed 30.05.2020). 
10. Official site of the State Migration Service of Ukraine. URL: https://dmsu.gov.ua/pro-dms/zagalnainformacziya.html. (Accessed 30.05.2020).

11. Piskurska, H. V. (2019), "Stakeholder approach in ensuring the quality of higher education", Pedagogy, psychology and sociology, 1 (24), pp. 69-77.

12. About higher education: the law of Ukraine № 1556-VII.

URL: http://zakon.rada.gov.ua/laws/show/1556-18. (Accessed 30.05.2020).

13. Tymoshenkov, I. V., Nashchekina, O. M. (2012), “ Subjects, agents, actors and stakeholders in economic research of education", Vcheni zapysky KHHU «NUA», 18(1), pp.167-176.

14. Stepanenko, K. I., Perfilyeva, Ye. V., (2018), Uchastiye zainteresovannykh storon $v$ prinyatii resheniy: teoriya $i$ praktika vzaimodeystviya [Participation of stakeholders in decision-making: theory and practice of interaction], ed. E. V. Perfilieva. Novokuznetsk: InEkA, Russian Federation.

15. Fomenko, K. M. (2012), "The role of the public employment service in the professional orientation of student youth", Naukovyy poshuk molodykh doslidnykiv : zbirnyk naukovykh prats' studentiv, 8, pp. 5-13.

\title{
Аннотация
}

Анна Воронцุова, Артем Артюхов, Вероника Барвинок

\section{ИДЕНТИФИКАЦИЯОСНОВНЫХ СТЕЙКХОЛДЕРОВ В СИСТЕМЕ ОБРАЗОВАНИЯ В ТЕЧЕНИЕ ЖИЗНИ ДЛЯ ПРЕДУПРЕЖДЕНИЯ ТРУДОВОЙ ЭМИГРАЦИИ}

\begin{abstract}
Исследованы теоретическая сущность понятия «стейкхолдеры» как основную категорию теории заинтересованных сторон и рассмотрены основные классификационные признаки, по которым можно выделить стейкхолдеров, в соответствии с различными научными подходами. На базе этого были проанализированы основные стейкхолдеры системы образования на протяжении жизни и рынка труда как места трудовой миграции и предложено их ранжирование по уровню и степени влияния, принадлежностью к государству и качественным характеристикам.
\end{abstract}

Ключевые слова: стейкхолдеры, теория заинтересованных сторон, классификация, система образования.

\section{Summary}

Anna Vorontsova, Artem Artyukhov, Veronika Barvinok

\section{IDENTIFICATION OF MAIN STAKEHOLDERS IN THE LIFELONG EDUCATION SYSTEM TO PREVENT LABOR EMIGRATION}

This article focuses on the theoretical identification and classification of key stakeholders in the lifelong learning system to prevent labor migration. For this purpose, the following general scientific methods were used: analysis and synthesis, comparison, classification and grouping, etc. The theoretical essence of the term of "stakeholder" as the main category of stakeholder theory based on the approach of management and review of the development of this approach is investigated. The main classification features by which stakeholders can be distinguished, according to different scientific approaches, are considered. Based on this, the main stakeholders of the lifelong learning system and the labor market as a place of labor migration were identified. These include the main state bodies in this field (legislative and executive), international organizations, business and non-governmental organizations, as well as directly participants in the educational process (management of educational institutions, students, parents, staff, etc.). Criteria for sorting stakeholders in education and employment spheres were selected on the basis of existing ones presented in the economic and social fields. All stakeholders were classified: by level (micro-, meso- and macro-) and degree of influence (important, medium, low), by statehood (internal and external) and qualitative characteristics (inactive, discretionary, demanding, dominant, dangerous, dependent, definitive).

Key words: stakeholders, stakeholder theory, classification, education system. 